\title{
Effect of Leaf Shading on Flowering Processes of Sugarcane ${ }^{1}$
}

\author{
Teh-ling Chu and J. L. Serapión ${ }^{2}$
}

\begin{abstract}
The effect of leaf shading on the regulation of sugarcane flowering processes by young expanding leaves was investigated.

A severe flowering repression produced by shading the leaves with aluminum foil, for one week at the onset of expansion, suggests that the leaf is highly capable of perceiving the critical photoinductive light and of producing a flowering stimulus during its emergence from a tightly rolled spindle. Both floral induction and time of tassel emergence were significantly affected.

A persistently significant suppression of floral induction as a result of leaf shading in stools having variable proportions of treated and untreated stalks demonstrated that individual stalks proceed more or less independently with their flowering processes within a stool complex. No evidence was found of interstalk transport of a flowering stimulus. It is suggested that the effectiveness of leaf shading within treated stalks is very possibly a translocation phenomenon.
\end{abstract}

\section{INTRODUCTION}

Burr (2) concluded from his work on sugarcane flowering that light causes a critical factor to be produced in the leaf which is subsequently transmitted through conducting tissue to the bud. Defoliation experiments by Chu and Serapión $(3,4,5)$ showed expanding leaves or leaves just fully expanded to be the most effective in producing a flowering stimulus. This sensitivity appeared to diminish gradually with increasing leaf age.

Coleman (6) summarized schematically the flowering processes of sugarcane in which the first step is a high intensity light reaction in the leaves, specifically requiring at least 12 hours duration, and presumably producing compounds with critical minimum levels required for the success of subsequent dark reactions. Vince (10) found that in both long- and short-day plants the length of the night is a critical factor in flowering but its effect

1 Manuscript submitted to the Editorial Board October 18, 1974.

2 Plant Breeder and Assistant Agronomist, respectively, Gurabo Substation, Agricultural Experiment Station, Mayagüez Campus, University of Puerto Rico, Rfo Piedras, P. R. The authors wish to express their sincere appreciation to Dr. A. G. Alexander, Plant Physiologist, for his valuable suggestions in the preparation of this manuscript. 
is not independent of the length of the preceding photoperiod. Borthwick et al. (1) concluded from their work on plant responses to high-energy radiation that three photoreactions and five dark reactions are probably involved in the interconversion of red and far-red forms of phytochrome.

In sugarcane the mechanisms by which light and dark reactions lead to a flowering stimulus production, and the transport of this stimulus from leaves to the apical meristem, remain almost totally obscure. In 1964 Hartt and Kortschak (7) reported that the complete darkening of detached blades reversed the direction of sucrose transport from basipetal to acropetal. Removing the apex of attached blades restricted the normal (basipetal) translocation of sucrose (8). If one assumes that flowering stimuli utilize the transport pathways and driving forces involved in sucrose translocation, it follows that leaf shading might also disrupt stimuli accumulation sufficiently to prevent floral induction. The present investigations were designed to determine the effects of leaf shading on regulation of flowering processes by young expanding leaves.

\section{MATERIALS AND METHODS}

\section{EXPERIMENT 1}

Two-eye cuttings of the variety NCo 310 were planted in the field in mid-January, 1973. Seven weeks thereafter all plants were fertilized with 500 pounds per acre of a 15-5-10 fertilizer. Fourteen irrigations were applied during the early growing season and the photoinductive period.

Leaf-shading treatments were performed between August 1 and September 21 , the critical period of flowering stimulus production in NCo 310 $(1,3)$. Employing 20 adult plants per treatment, leaves were sheathed in aluminum foil at the onset of expansion and remained darkened for one week. The enveloping foil was open at each end to permit air circulation. It was extended periodically to accommodate expanding leaf tissue. Control leaves retained their normal exposure to sunlight. All suckers were removed prior to treatment and at 2-week intervals thereafter.

Tassel counts were recorded at 3-day intervals dating from the first appearance of a visible inflorescence. Stalks failing to produce a tassel were dissected on December 20 and their flowering status recorded. Percentages of stalks achieving floral initiation and tassel emergence were computed and subjected to statistical analysis by the paired $t$-test.

\section{EXPERIMENT 2}

Two-eye cuttings of NCo 310 were propagated in accordance with experiment 1. A series of four leaf-shading treatments were established on the basis of the percentage of stalks to be treated per stool, i.e., 100, 70, 
30 and 0 percent. A randomized block design was used with 16 replicates of each treatment. Beginning August 7 and employing 16 adult plants per treatment, leaves ranked $-1^{3}$ were darkened for two weeks with an aluminum foil sheath. Younger leaves were treated at 2-week intervals up to September 21. Since new leaves emerged at the rate of about one per week during the treatment interval, those ranked as -1 when darkened had become the rank +1 by the end of their 2-week treatment. Leaf tips extending beyond the aluminum shield were trimmed on August 14 and 28. Flowering data were recorded and processed as in experiment 1.

TABLE 1.-Effects of leaf shading on floral initiation and tassel emergence in variety $\mathrm{NCo} 310$

\begin{tabular}{|c|c|c|c|c|c|}
\hline Treatment & $\begin{array}{c}\text { Stalks } \\
\text { treated }\end{array}$ & $\begin{array}{c}\text { Stalks } \\
\text { initiated }\end{array}$ & $\begin{array}{c}\text { Average } \\
\text { initiation }\end{array}$ & $\begin{array}{l}\text { Tassels } \\
\text { emerged }\end{array}$ & $\begin{array}{l}\text { Average tassel } \\
\text { emergence }\end{array}$ \\
\hline \multirow{4}{*}{$\begin{array}{l}\text { Leaves shaded } \\
\text { Control }\end{array}$} & Number & Number & Percemt & Number & Percent \\
\hline & 306 & 249 & 81.4 & 239 & 78.1 \\
\hline & 333 & 320 & 96.1 & 319 & 95.8 \\
\hline & & & $\begin{array}{r}5 \text { percent } \\
=9.15 \\
1 \text { percent } \\
=12.52\end{array}$ & & $\begin{array}{c}\text { P } 5 \text { percent } \\
=8.96 \\
1 \text { percent } \\
=12.26\end{array}$ \\
\hline
\end{tabular}

\section{RESULTS}

\section{EXPERIMENT 1}

Both floral initiation and tassel emergence were significantly reduced by leaf shading (table 1). With reference to flowering time, a substantial delaying effect was also brought about by this treatment (fig. 1).

\section{EXPERIMENT 2}

Among treated stalks within the same stool, floral initiation and tassel emergence were again significantly reduced by leaf shading (table 2). This effect was essentially constant regardless of the percentage of stalks remaining untreated within the stool. Among the latter, neither tasseling percentage nor time of tassel emergence were affected by shading the leaves of companion stalks (table 2). Time of flowering was also unaffected (fig. 2).

\section{DISCUSSION}

The present results verify earlier findings $(3,4,5$,$) in which young expand-$ ing leaves play a predominant role in the flowering processes of sugarcane.

The leaf having the highest visible dewlap was designated +1 . 


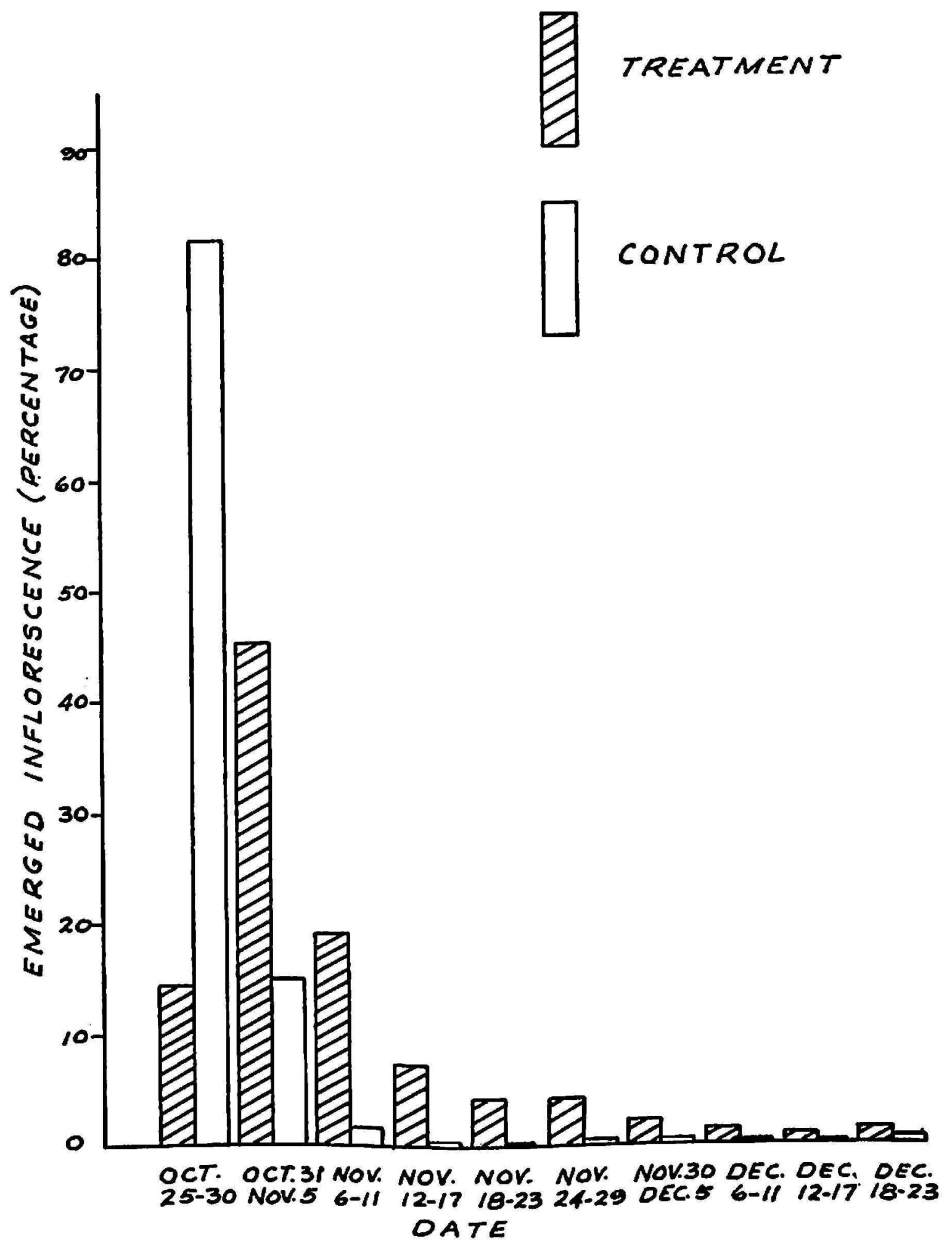

FIG. 1.-Effects of leaf shading on the extent and time of tassel emergence in NCo 310 .

The severe repression produced by leaf shading for one week suggests that leaf -1 is highly capable of perceiving photoinductive light and of producing a flowering stimulus during its emergence from a tightly rolled spindle. The specific light reactions interrupted by shading may involve the inter- 
conversion of red and far-red forms of phytochrome thought to be essential in the control of flowering hormone synthesis $(1,10)$. In a practical sense, it is also evident that flowering can be suppressed discretely without amputating or desiccating a leaf otherwise needed for the manufacture of sugar.

The confinement of leaf shading effects to those stalks actually treated suggests that individual stalks proceed more or less independently with their flowering processes within a stool complex. Whether a given stalk will flower or not flower will depend upon its physiological maturity and its success in completing requisite light and dark reactions. Present results do

TABLE 2.-Effects of leaf shading on floral initiation and lassel emergence in sugarcane stools having variable proportions of trealed and untreated stalks in variely NCo $\$ 10$

\begin{tabular}{|c|c|c|c|c|c|c|}
\hline $\begin{array}{l}\text { Leaf shading, } \\
\text { as percent of } \\
\text { stalks per } \\
\text { stool }\end{array}$ & $\begin{array}{l}\text { Stalks per } \\
\text { treatment }\end{array}$ & $\begin{array}{l}\text { Stalks } \\
\text { treated }\end{array}$ & $\begin{array}{l}\text { Average floral } \\
\text { initiation of } \\
\text { treated stalks }\end{array}$ & $\begin{array}{l}\text { Average tassel } \\
\text { emergence of } \\
\text { treated stalks }\end{array}$ & $\begin{array}{l}\text { Untreated } \\
\text { stalks }\end{array}$ & $\begin{array}{l}\text { Average tassel } \\
\text { emergence among } \\
\text { untreated } \\
\text { stalks }\end{array}$ \\
\hline & Number & Number & Percent & Percent & Number & Percent \\
\hline 100 & 234 & 234 & $17.7 a^{1}$ & $4.1 a^{1}$ & 0 & - \\
\hline 70 & 236 & 164 & $25.3 a$ & $6.3 \mathrm{a}$ & 72 & $98.8 \mathrm{a}^{1}$ \\
\hline 30 & 240 & 71 & $25.6 \mathrm{a}$ & $6.6 \mathrm{a}$ & 169 & $98.3 a$ \\
\hline \multirow[t]{2}{*}{ Control } & 234 & 234 & $97.5 b$ & $97.0 \mathrm{~b}$ & 234 & $97.0 \mathrm{a}$ \\
\hline & & & $\begin{array}{l}\text { LSD } \\
\text { P } 5 \text { percent } \\
=15.73 \\
1 \text { percent } \\
=20.94\end{array}$ & $\begin{array}{l}\text { LSD } \\
\text { P } 5 \text { percent } \\
=6.64 \\
1 \text { percent } \\
=8.84\end{array}$ & & 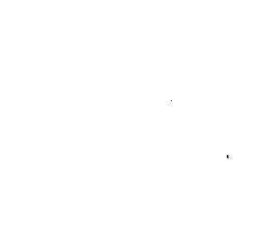 \\
\hline
\end{tabular}

${ }^{1}$ Mean values in the same column bearing unlike letters differ significantly ( $P$ $<.01)$.

not disprove interstalk movement of flowering stimuli, perhaps in the nature of interstalk sucrose transport (9), but in a quantitative sense such movement has been too small to be decisive in achieving a critical threshold level.

On the other hand, the effectiveness of leaf shading within the treated stalk is very possibly a translocation phenomenon. Available evidence $(7,8)$ suggests that light exclusion as herein practiced will severely alter the movement of sucrose from leaf to sink tissues. To the extent that flowering stimuli utilize the same transport mechanism, especially under conditions such that the quantity and timing of hormone accumulation are utterly critical, leaf shading may have affected flowering via the movement rather than synthesis of a flowering factor. 


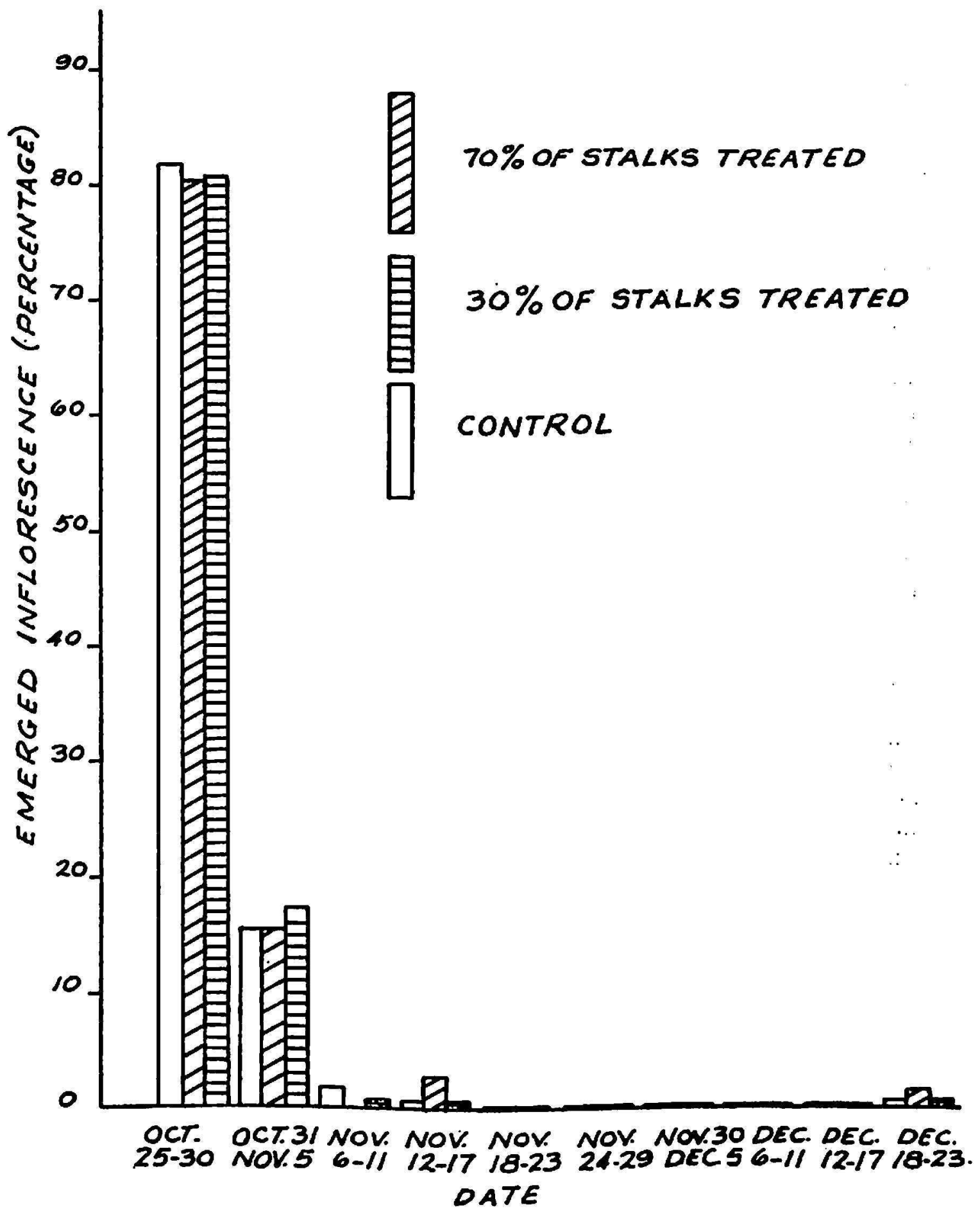

Fig. 2.-Frequency distribution for tassel emergence in sugarcane stools having variable proportions of treated and untreated stalks, var. NCo 310.

\section{RESUMEN}

Se estudió el efecto en el florecimiento de la caña de azúcar mediante el oscurecimiento producido al envolver con papel de aluminio las hojas nuevas que se encuentran formando un apretado rollo pero que están próximas a expandirse completamente. 
El efecto de la supresión de la luz debido al oscurecimiento de las hojas en distintas proporciones en las cañas de una misma cepa demostró que los tallos dentro del conjunto son más o menos independientes en su proceso de florecimiento.

No se halló evidencia de que el estímulo floral se transporte, lo que parece indicar que la florescencia es afectada más bien por la interrupción del movimiento que por una disminución en la síntesis de las substancias que la estimulan.

\section{LITERATURE CITED}

1. Borthwick, H. A., Hendricks, S. B., Schneider, M. J., Taylorson, R. B., and Toole, V. K., The high-energy light action controlling plant responses and development, Proc. Nat. Acad. Sci. U. S. 64: 479-486, 1969.

2. Burr, G. O., The flowering of sugarcane, Rept. Hawaiian Sugar Technol. pp. 47-49, 1950.

3. Chu, Teh-ling and Serapión, J. L., The role of leaves in production of flowering stimulus in sugarcane, Proc. Int. Soc. Sugar Cane Technol. 14: 365-71, 1971.

4. - Effect of individual leaf-trimming on flowering in sugarcane, J. Agr. Univ. P. R. 56(4): 403-9, 1972.

5. - Further studies on the role of leaves in sugarcane flowering, J. Agr. Univ. P. R. 58(4): 393-405, 1974.

6. Coleman, R. E., Physiology of flowering in sugarcane, Proc. Int. Soc. Sugar Cane Technol. 13: 992-1000, 1968.

7. Hartt, C. E. and Kortschak, H. P., Sugar gradients and translocation of sucrose in detached blades of sugarcane, Plant Physiol. 39(3): 460-474, 1964.

8. - - - and Burr, G. O., Effects of defoliation, eradication, and darkening the blade upon translocation of ${ }^{14} \mathrm{C}$ in sugarcane, Plant Physiol. 39(1): 15-22, 1964.

9. Lang, A., Physiology of flowering, Annu. Rev. Plant Physiol. 3: 265-306, 1952.

10. Vince, D., Phytochrome and flowering, Phytochrome (Mitrakos, K. and Shropshire, W., Jr.) pp. 257-91, 1972, Academic Press, London and New York. 